\title{
Hepatoprotective Effect of Coumarin and Chlorophyll Against Aflatoxicosis in Rat
}

Abdel-Latif, M. S. ${ }^{1}$; K. M. Elmeleigy ${ }^{2}$; Marwa M. S. Khattab ${ }^{3}$ and Sara M. Mohamd ${ }^{2}$

${ }^{1-}$ Biochemistry Department, Faculty of Agriculture, Cairo University, Giza, Egypt.

${ }^{2-}$ Regional Center For Food and Feed, Agricultural Research Center, Ministry of Agriculture, Giza, Egypt.

${ }^{3-D e p a r t m e n t ~ o f ~ P a t h o l o g y, ~ F a c . ~ o f ~ V e t e r i n a r y ~ M e d i c i n e, ~ C a i r o ~ U n i v e r s i t y, ~ G i z a ~ S q u a r e, ~ G i z a, ~}$ Egypt. Postal code 12211

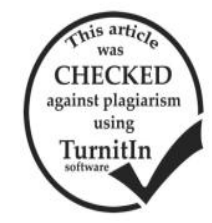

\begin{abstract}
Aflatoxin contamination of animal diet is still a major problem for breeders since it hasadverse effects on animal health and productivity. This study was carried out to investigate the effect of using coumarin and/or chlorophyll in rat diet against aflatoxicosis. Fifty four rats were randomly assigned into 7 groups "6 rats each" and group 5 "12 rats". Group 1 was negative control. Group 2 received water with coumarin $0.5 \%$. Group 3 received water with chlorophyll $0.5 \%$. Group 4 received water with coumarin $0.5 \%$ and chlorophyll $0.5 \%$. Group 5-8 received basal diet with aflatoxin $\mathrm{B}_{1} 1000 \mathrm{ppb}$. Group 6-8 were administered similar treatments as groups 2-4. The experiment ended after 8 weeks. Water and feed consumption were measured and feed conversion rate were calculated. Random glucose level, total lipid, total cholesterol, triglyceride, total protein, ALT , AST, creatinine and urea were determined in serum. Histopathological examination of liver, kidney and pancreas was performed. The conversion rate was significantly low in group 5 compared to groups 6-8. The serum glucose, cholesterol, AST and ALT were elevated in group 5 compared to groups 6-8. The liver lesions observed in group 5 represented in vacuolation and necrosis were alleviated in groups 6-8. The necrosis and inflammatory cells infiltration in pancreas of group 5 were absent in groups 6-8. In conclusion, the coumarin and or chlorophyll possessed a hepatoprotective effect against aflatoxincosis.
\end{abstract}

Keywords: Aflatoxin, Coumarin, Chlorophyll, Histopathological Examination

\section{INTRODUCTION}

Acute aflatoxicosis causes hepatitis, hemorrhage, immune suppression, genetic damage (carcinogenicity, teratogenicity and mutagenicity) and death. Growth impairment and lowering of reproductive performance are the most sensitive clinical signs of chronic aflatoxicosis (Abdelhamid, 2005 a,b and 2009; Shehata,2010 and Shouman et al., 2012). Scientific efforts were directed towards using physical, chemical and biological techniques for detoxification or inactivation of aflatoxins (Abdelhamid et al., 2002 and Agag,2003). These techniques have not been used on a commercial scale due to high costs, the need for special facilities, losses of important nutrients and the questionable safety of chemical degradation products of aflatoxins. One of the effective methods to overcome the toxic and carcinogenic effects of aflatoxins is to enhance aflatoxin metabolism towards its detoxification in humans or animals (Tulayakul et al.,2007).

More than 1300 coumarins have been identified from natural sources especially green plants (Hoult and Paya, 1996). Coumarins are antioxidants, contain the nucleus of benzo- $\alpha$-pyrone and occur in plants like Tonka beans, Sweet clover, Wood ruff, Cassia leaf (Lake et al.,1989). It is present also in a variety of plants families like Loganiaceae (Bhattacharyya et al.,2008), Orchidaceae, Leguminaceae, Rutaceae, Umbelliferae and Labiatae (Vyas et al.,2009). The synthetic coumarin (4methyl-7 hydroxycoumarin) derived from resorcinol and ethyl aceto-acetate in presence of concentrated sulphuric acid is structurally close to scopoletin, being a coumarin derivative. Naturally derived and synthetic coumarins have been used in treatment of oedemas (Clasley- Smith et al., 1993), and possessed anti-canceror anti- tumorigenic (Prince et al., 2009 and Battacharyya et al.,2009),antimutagenic (Pillai et al.,1999), antibacterial (Devvienne et al., 2005), anticoagulants, anti- thrombotic and vasodilatory effects (Hoult andPaya,1996).
Clorophyllin (CHL), a water-soluble form of chlorophyll, was recently evaluated as chemopreventaive agent in a population at high risk for exposure to aflatoxin and subsequent development of hepatocellular carcinoma (Kensler et al.,2002 and Kumer et al.,2012). CHL, which is used extensively as a food colorant, has numerous medicinal applications. CHL is a safe and effective agent suitable for use in individuals unavoidably exposed to aflatoxins (Enger et al.,2003). Naturally chlorophyll and CHL strongly inhibits aflatoxin $\mathrm{B}_{1}$ prenoplasia biomarkers, stomach and liver tumor in rats and rainbow trout (Sudakin,2003; Simonich et al., 2007 and 2008). Moreover, the CHL was more effective than chlorophyll$\mathrm{A}$ in reducing aflatoxin $\mathrm{B}_{1}-$ DNA adduct and liver tumor (Dashwood et al.,1998).

The Goal Of The Research

It is known that aflatoxins are cause serious Effects so that these effects can be mitigated by using some natural compounds.

\section{MATERIALS AND METHODS}

\section{Animals}

Fifty four Sprague - Dawley male albino rats with average body weight $90 \pm 10 \mathrm{~g}$ was used. Were obtained from the farm of The Egyptian Organization of Biological products and Vaccines, Egypt. The animals were housed individually in stainless steel cases in a controlled environment $25 \pm 5^{\circ} \mathrm{C}, 50-60 \%$ relative humidity and 12 hours light- dark cycle, all over the experimental period (8 weeks). Free access to water and maintenance ration twice daily were available. This study was in accordance with Institutional Animal Use and Care Committee (IACUC) guidelines, Cairo University.

\section{Coumarin preparation}

Coumarin (4-Methyl-7-hydroxycoumarin) was prepared according to method of Furniss et al. (1989)which is summarized as follow: 1 liter of concentrated sulphuric acid was placed in a 3 liter necked flask. The flask was immersed in an ice bath; a solution of 
$100 \mathrm{~g}(0.91 \mathrm{~mol})$ of resorcinol in $134 \mathrm{~g}$ of ethyl acetoacetate was added drop wise and with stirring for $2 \mathrm{hrs}$. The reaction mixture was kept at room temperature for about $18 \mathrm{hrs}$., then it was poured with vigorous stirring into a mixture of crushed ice and water, the crude yield (yield = $155 \mathrm{~g}, 97 \%$ concentration) was collected, recrystallization in ethanol $95 \%$ and air dried .The dried coumarin was added to water $0.5 \%$. Coumarin standard from sigma Aldrich .

\section{Chlorophyll preparation}

All chlorophyll extractions were performed under dim green light to minimize photo - oxidative reaction (Shio, 2006). Fresh spinach leaves were purchased from local market. Spinach leaves were separated from the stem and then about $100 \mathrm{~g}$ were weighed and put into a blender. Cold acetone was added as much as $500 \mathrm{ml}$. Then the spinach leaves were grinded in a blender for about $3 \mathrm{~min}$. The filtrate of crude chlorophyll was separated using a Buchner funnel with a Whatman filter paper No.1. The residual solids that are not filtered was washed with $100 \mathrm{ml}$ of acetone. Then the filtrate was added to dioxane approximately one seventh of its volume. After that, the mixture was added with deionized water as much as one seventh of the volume of the mixture by drop wise and then stirred using a magnetic stirrer. The mixture was precipitated by storing in the freezer at $-20^{\circ} \mathrm{C}$ for $1 \mathrm{hr}$ until dark green precipitate was obtained at the bottom of the solution and a yellow liquid on top. The precipitate of crude chlorophyll was separated by filtration using two layers of Whatman filter paper No. 1 with a Buchner funnel. The solution then was added with dioxane as much as one seventh of the volume of the solution and also deionized water as much as one seventh of the volume of the solution while slowly stirred. The precipitation was then performed for the second time in the same way at -20 ${ }^{\circ} \mathrm{C}$ for $1 \mathrm{hr}$. After that the precipitate was filtered using a Buchner funnel and two layers of Whatman paper No.1. The crude chlorophyll solids were filtered and diluted with acetone until colorless paper return. Then a solution of crude chlorophyll is evaporated from the solvent so that only the remaining solid green crude chlorophyll was left. Thus, the chlorophyll was dissolved using the small volume of diethyl ether in order to obtain the chlorophyll solution prior to any further separation using column chromatography according to (Suendo et al., 2010).

\section{Aflatoxin preparation}

Aflatoxin production was carried out according to Davis et al. (1966) using liquid media (2\% yeast extract and 20\% sucrose) and Aspergillusflavus stain ( NRRL 3145). The media which contained detectable amount of aflatoxin was mixed well with the basal diet to get the aflatoxin- contamination diet. The total aflatoxin content in liquid medium was determined according to Roos et al. (1997) and AOAC. (2006) method using monoclonal antibody columns for total aflatoxins (Vicam Science Technology, water town, MA, USA). Aflatoxin identification was performed by a modification of the HPLC - AFLATEST procedure Agillent 1200 series USA. HPLC equipment with two pumps, column C18, Lichrospher $100 \mathrm{RP}-18$, $(5 \mathrm{Nm} \times 25 \mathrm{~cm})$ was used. The mobile phase consisted of water: methanol: acetonitrile (54: 29:17, v/v/v) at flow rat of $1 \mathrm{~mL} / \mathrm{min}$. The excitation and emission wavelengths for all aflatoxins were 362 and $460 \mathrm{~nm}$ (Flourcenses detector), respectively.

\section{Experimental design}

Fifty four rats were randomly assigned into 7 groups "6 rats each" and group 5 "12 rats". Group 1 received basal diet (negative control) (G1). Group 2 received basal diet and water with coumarin $0.5 \%$ (G2). Group 3 received basal diet and water with chlorophyll $0.5 \%$ (G3). Group 4 received basal diet, water with coumarin $0.5 \%$ and chlorophyll $0.5 \%$ (G4). Group 5 received basal diet with aflatoxin $B_{1} 1000 \mathrm{ppb}$ (positive control) (G5). Group 6 received basal diet with aflatoxin and water with coumarin $0.5 \%$ (G6). Group 7 received basal diet with aflatoxin and water with chlorophyll $0.5 \%$ (G7). Group 8 received basal diet with aflatoxin and water with coumarin $0.5 \%$ and chlorophyll $0.5 \%$ (G8). The ingredients of basal diet are shown in Table 1. Daily fresh water was available the whole time. At the last day of the experiment, the rats were fasted over night. The experiment was terminated after 8 weeks and animals were euthanized by cervical decapitation.

Table 1.Composition of basal diet

\begin{tabular}{lc}
\hline Ingredients & $\mathbf{\%}$ \\
\hline Casein & 20.0 \\
Corn starch & 65.0 \\
Mineral mix $^{2}$ & 3.5 \\
Vitaminmix $^{2}$ & 1.0 \\
DL-Methionine & 0.3 \\
Choline bitartrate & 0.2 \\
Cellulose powder & 5.0 \\
Corn oil & 5.0
\end{tabular}

1-Based on AIN-76 " American Institute of Nutrition"

\begin{tabular}{lclc}
\hline Vitamins $^{2}$ based on AIN-76 & Minerals $^{2}$ based on AIN-76 \\
\hline Vitamin A & $4.00 \mathrm{IU} / \mathrm{g}$ Calcium & $\% 0.52$ \\
Vitamin D3 & $1.00 \mathrm{IU} / \mathrm{g}$ Phosphorus & $\% 0.44$ \\
Alpha-Tocopherol & $64.24 \mathrm{IU} / \mathrm{kg}$ Potassium & $\% 0.38$ \\
Thiamine & $5.90 \mathrm{ppm}$ Sodium & $\% 0.11$ \\
Pantothenic Acid & $15.26 \mathrm{ppm}$ Magnesium & $\% 0.05$ \\
Choline & $104.00 \mathrm{ppm}$ Iron & $34.25 \mathrm{ppm}$ \\
Pyridoxine & $7.1 \mathrm{ppm}$ Zinc & $36.76 \mathrm{ppm}$ \\
Folic Acid & $2.10 \mathrm{ppm}$ Manganese & $59.34 \mathrm{ppm}$ \\
Biotin & $0.21 \mathrm{ppm}$ Copper & $6.73 \mathrm{ppm}$ \\
Vitamin B12 & $10.10 \mathrm{mcg} / \mathrm{kgCobalt}$ & $0.02 \mathrm{pm}$ \\
Vitamin K & $0.50 \mathrm{ppm}$ Iodine & $0.21 \mathrm{ppm}$ \\
\hline
\end{tabular}

\section{Prepared as Rodent Diet AIN-76A}

Serum analysis

Blood samples were collected from each rat from the retrooribtal vein and were received into clean dry centrifuge tubes. Serum was separated by centrifugation at $3000 \mathrm{rpm}$ for 15 minutes and kept in deep-freezer at -20 ${ }^{\circ} \mathrm{C}$ until used for estimation of random glucose level, total lipid, total cholesterol, triglyceride, total protein, ALT , AST, creatinine and urea by using Biodiagnostic Kits.

\section{Histopathological examination}

Liver, kidneys and pancreas samples were collected at the end of the experiment and were fixed in $10 \%$ neutral buffered formalin solution for at least $48 \mathrm{hrs}$. Tissue specimens were processed using routine paraffin embedded technique in which tissues was dehydrated in ascending concentration of alcohol and cleared in xylene. Sections $3-5 \mu$ thick were made using microtome (Leica 2135) and stained with Haematoxylin and Eosin (H\&E) 
(Suvarna et al., 2012). The histopathological alterations in liver, kidney and Pancreas were examined by light microscopy and photographed using camera Olympus XC30 (Tokyo, Japan).

\section{RESULTS AND DISCUSSION}

\section{Weight gain and water consumption}

Aflatoxin contaminated diet decreased total and daily body weight gain, daily feed intake and water consumption (Table 2). These results agree with the finding of Shehata (2002 and 2010), Meshreky et al.(2007) on rabbits and Shehata et al. (2009 a,b) and Mehrim et al. (2016) on fish. The reduction in body weight gain by aflatoxin is not only due to depression of feed intake, but may also be due to the reduction in metabolism of protein, lipids, carbohydrate and dissolved vitamin in lipid (Maria and Askar,2008).Also, it might be due to detoxification process in the body utilizing glutathione enzymes. Glutathione is the intracellular antioxidant (Deng et $a l ., 2010)$ and partly composed of methionine and cysteine, hence this detoxification process depletes the metabolic availability of methionine leading to poor growth and feed conversion. Adding coumarin to diet improved growth performance, the beneficial effect of coumarin may be due to: (1) reduction $\mathrm{AFB}_{1}$-DNA adducts formation by both liver and intestinal microsomes. Coumarin enhanced aflatoxicol formation; therefore, decrease $\mathrm{AFB}_{1}$-DNA adduct, because direct interaction of aflatoxicol epoxide with DNA is major compared with AFB1 epoxide, (2) enhancement of glutathione -s- transferase (GST) activity in the intestine to conjugate $\mathrm{AFB}_{1}$, (3) suppression of $\mathrm{P} 450$ enzyme activity in the lives and the enhancement of GST in the intestine (Tulayakul et al.,2007), and (4) improving liver function and body health.

The beneficial effect of CHL may be due to : (1) CHL form molecules complexes with carcinogens material and blockingthen bioavailability therefore reduce the hazard effects on organs body functions,(2) CHL modify the genotoxic effects of aflatoxin B1 by inhibiting bioactivation pathways and stimulating detoxification pathways (Sudakin,2003), (3) CHL enhance the activities of antioxidant enzymes such as glutathione peroxidase, superoxide dismutase catalase and glutathione -stransferase,indicating that $\mathrm{CHL}$ possess a potent protective

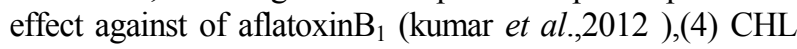
reduce multi organs aflatoxin $B_{1}$-DNA adducts ( Simonich et al.,2007).

Table 2. Body weight gain, food intake and Consumer water of different experimental group for 8 week

\begin{tabular}{|c|c|c|c|c|c|c|c|c|c|}
\hline Treatments & $\begin{array}{c}\text { Initial } \\
\text { weight } \\
\text { (g) }\end{array}$ & $\begin{array}{c}\text { Final } \\
\text { weight } \\
\text { (g) }\end{array}$ & $\begin{array}{c}\text { Body } \\
\text { Weight gain } \\
\text { (g)Bwg" } \\
\end{array}$ & $\begin{array}{c}\text { Bwg / } \\
\text { Initial } \\
\text { weight(\%) } \\
\end{array}$ & $\begin{array}{c}\text { Weekly } \\
\text { body weight } \\
\text { gain }(\mathrm{g}) \\
\end{array}$ & $\begin{array}{l}\text { Average daily } \\
\text { t Feed Intake } \\
\text { (g) }\end{array}$ & $\begin{array}{c}\text { Feed } \\
\text { conversica } \\
\text { Feed/gain } \\
\end{array}$ & $\begin{array}{c}\text { Water } \\
\text { consumption } \\
(\mathrm{ml}) / \text { day }\end{array}$ & $\begin{array}{c}\begin{array}{c}\text { Weight gain } \\
\text { from the } \\
\text { control\% }\end{array} \\
\end{array}$ \\
\hline Control & $\begin{array}{c}117.58 \pm \\
1.63\end{array}$ & $\begin{array}{c}241.25 \pm \\
1.39^{\mathrm{c}}\end{array}$ & $\begin{array}{l}123.67 \pm \\
10.92^{\mathrm{ab}}\end{array}$ & 105.18 & 15.46 & $\begin{array}{c}21.00 \pm \\
0.62^{\mathrm{b}}\end{array}$ & 1.36 & $\begin{array}{l}14.9 \pm \\
1.37^{\mathrm{ab}}\end{array}$ & 100 \\
\hline Coumarin & $\begin{array}{c}112.17 \pm \\
1.49\end{array}$ & $\begin{array}{c}280.5 \pm \\
2.25^{\mathrm{a}}\end{array}$ & $\begin{array}{c}168.83 \pm \\
16.89^{\mathrm{a}}\end{array}$ & 150.07 & 21.10 & $\begin{array}{c}25.60 \pm \\
0.82^{\mathrm{b}}\end{array}$ & 1.21 & $\begin{array}{l}17.6 \pm \\
1.22^{\mathrm{a}}\end{array}$ & 142.68 \\
\hline Chlorophyll & $\begin{array}{c}118.67 \pm \\
169\end{array}$ & $\begin{array}{c}230.33 \pm \\
0.79^{\mathrm{d}}\end{array}$ & $\begin{array}{l}111.67 \pm \\
12.95^{\mathrm{ab}}\end{array}$ & 94.09 & 13.96 & $\begin{array}{l}21.82 \pm \\
1.21^{\mathrm{b}}\end{array}$ & 1.56 & $\begin{array}{l}15.1 \pm \\
1.55^{\mathrm{ab}}\end{array}$ & 106.48 \\
\hline $\begin{array}{l}\text { Coumarin }+ \\
\text { Chlorophyll }\end{array}$ & $\begin{array}{c}117.67 \pm \\
2.14\end{array}$ & $\begin{array}{l}260 \pm \\
1.15^{\mathrm{b}}\end{array}$ & $\begin{array}{c}142.33 \pm \\
9.06^{\mathrm{ab}}\end{array}$ & 121 & 17.80 & $\begin{array}{c}41.77 \pm \\
0.50^{\mathrm{a}}\end{array}$ & 2.35 & $\begin{array}{l}16.9 \pm \\
0.96^{\mathrm{a}}\end{array}$ & 115.04 \\
\hline Aflatoxin & $\begin{array}{c}114.33 \pm \\
2.2\end{array}$ & $\begin{array}{l}221.67 \pm \\
1.64^{\mathrm{e}}\end{array}$ & $\begin{array}{c}107.33 \pm \\
21.21^{\mathrm{b}}\end{array}$ & 93.88 & 17.89 & $\begin{array}{c}21.37 \pm \\
0.90^{\mathrm{b}}\end{array}$ & 1.20 & $\begin{array}{l}13.5 \pm \\
0.43^{b}\end{array}$ & 89.26 \\
\hline $\begin{array}{l}\text { Aflatoxin }+ \\
\text { Coumarin }\end{array}$ & $\begin{array}{c}127.17 \pm \\
1.65\end{array}$ & $\begin{array}{c}248.33 \pm \\
0.84^{\mathrm{c}}\end{array}$ & $\begin{array}{c}121.17 \pm \\
10.55^{\mathrm{ab}}\end{array}$ & 95.28 & 15.15 & $\begin{array}{l}33.90 \pm \\
3.11^{\mathrm{ab}}\end{array}$ & 2.24 & $\begin{array}{l}16.5 \pm \\
0.78^{\mathrm{a}}\end{array}$ & 90.59 \\
\hline $\begin{array}{l}\text { Aflatoxin }+ \\
\text { Chlorophyll }\end{array}$ & $\begin{array}{l}120 \pm \\
1.32\end{array}$ & $\begin{array}{c}226.33 \pm \\
1.41^{\mathrm{de}}\end{array}$ & $\begin{array}{c}106.33 \pm \\
12.25^{\mathrm{b}}\end{array}$ & 88.6 & 13.29 & $\begin{array}{l}29.47 \pm \\
2.86^{\mathrm{ab}}\end{array}$ & 2.22 & $\begin{array}{l}15.7 \pm \\
0.52^{\mathrm{ab}}\end{array}$ & 84.24 \\
\hline $\begin{array}{l}\text { Aflatoxin + Coumarin } \\
+ \text { Chlorophyll }\end{array}$ & $\begin{array}{c}121.5 \pm \\
1.04\end{array}$ & $\begin{array}{c}256.83 \pm \\
1.87^{\mathrm{b}}\end{array}$ & $\begin{array}{c}135.33 \pm \\
6.61^{\mathrm{ab}}\end{array}$ & 111.38 & 16.92 & $\begin{array}{l}28.42 \pm \\
2.0^{\mathrm{ab}}\end{array}$ & 1.68 & $\begin{array}{l}16.6 \pm \\
0.61^{\mathrm{a}}\end{array}$ & 105.89 \\
\hline
\end{tabular}

All values are represented as mean \pm S.E.

Means with different letters are significantly different $(\mathbf{p}<0.05)$.

H (Higher than normal rang), L ( Lower than normal rang)

\section{Biochemical findings}

Results in Table 3 revealed that positive controls (group receiving basal diet with aflatoxin) gave a significant increase in serum liver function enzymes, alanine amino transferase (ALT) and aspartate amino transferase (AST). Furthermore, this group showed significantly higher level of serum urea, creatinine, cholesterol and triglycerides as compared to healthy group fed the basal diet. Increasing AST and ALT activities may be due to hepatocellular necrosis or increasing the permeability of cell membrane (Zaky et al.,2000).On the other hand, the increased concentrations of urea and creatinine indicate kidney injury caused by aflatoxins toxicity. These results coincide with those reported by Zohair. (1996) in treated rats and those of Matri (2001) who reported that Japanese quail birds receiving contaminated feed with aflatoxin showed significantly higher serum total cholesterol, creatinine and urea. The total protein was significantly decreased in the group fed the aflatoxin contaminated diet. These finding were in accordance with previous studies (Abd El Baki et al.,2002 and Shehata, 2002 and 2010).Decreasing of serum protein may be attributed to degeneration of endoplasmic reticulum and inhibition of protein synthesis (Srivastava, 1984). Addition of coumarinor CHL alone and coumarin with CHL improved blood parameters measured. These results may be due to the effect of coumarin and CHL on detoxification of aflatoxin (Kelly et al.,2000 and Tulayakul et al.,2007) and improvement of body health (Prince et al.,2009). 
Table 3. Serum AST, ALT, urea, creatinine, total protein, glucose, total cholesterol and total triglycerides levels in the different experimental groups.

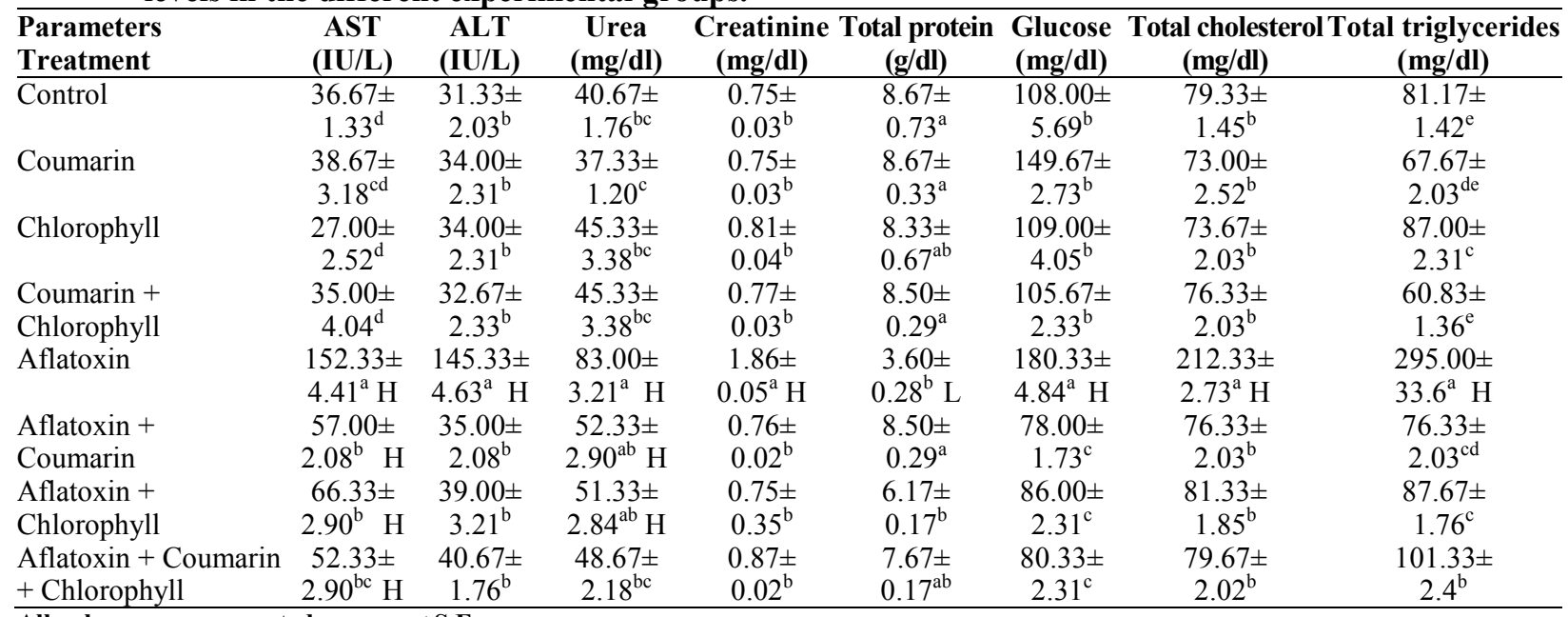

All values are represented as mean \pm S.E.

Means with different letters are significantly different $(\mathbf{p}<0.05)$.

$H$ (Higher than normal rang), L ( Lower than normal rang).

\section{Histopathological Findings}

In the current study, there was vacuolation of heptocytes, karyomegaly and binucleation of hepatocytic nuclei in the liver of rats administrated aflatoxin (Figure 1a) coinciding with the degenerative changes induced by aflatoxin administration in the hepatic tissues of rats (AbdelWahhab et al., 2002). Moreover, portal mononuclear inflammatory cells infiltration and focal areas of hepatocyte necrosis accompanied with mononuclear cells infiltration in the liver were demonstrated in the present study similar to histopathological changes recorded in previous studies (Naidu et al., 1991; Salem et al., 2001 and El-Shewy and Ebrahem, 2004) which showed that the main lesions in liver of rats exposed to aflatoxin were progressive hepatic degeneration, multifocal hepatic necrosis, bile ductular proliferation and areas of altered hepatocytes.

The liver histopathology of rats in the groups administered aflatoxin and receiving coumarin and/or chlorophyll exhibited an apparently normal hepatic structure in which the hepatocyte vacuolation and necrosis was almost diminished (Figure 1b, c, d). This improvement was more obvious in the group receiving coumarin and the group receiving coumarin and chlorophyll. Subsequently, the coumarin and chlorophyll is believed to have exerted a protective effect against aflatoxin toxicity. Similarly, in a previous study, the chemoprotective effect of coumarinwas evident against aflatoxin B1 induced mutations and cytotoxicity in the presence of chick embryo liver S9 but not with rat liver S9.It was said that coumarin reduced the invitro formation of aflatoxin B1 8, 9- epoxide involved in aflatoxin toxicity (Goeger et al., 1998). Furthermore, adding coumarin ( $2.5 \mathrm{~g}$ coumarin/ $\mathrm{Kg}$ diet) to aflatoxin $\mathrm{B} 1$ contaminated rabbit diet was found to be safe and practical method to minimize aflatoxin B1 toxicity (Helal et al., 2014).

Perivascular mononuclear inflammatory cells and interlobular edema and mononuclear inflammatory cells infiltration were demonstrated in the pancreas of rat administered aflatoxin in accordance with previous studies (Figure 1 e)(Beger et al., 2000 , Şimşek et al., 2007, andAbd El-Haleem and Mohamed, 2011).Aflatoxin ingestion leads to reactive oxygen species production that regulates chemokine receptor expression and also facilitates the recruitment and localization of polymorphonuclear leukocyte to the site of infection and inflammation (Shephard, 2003). Additionally, in this study, perivascular fibrosis in the pancreas was observed in the rats administered aflatoxin. Similarly, the pancreas revealed many collagen fibers, especially around ducts and blood vessels in previous studies (Abd El-Haleem and Mohamed, 2011). Stellate cells observed in both rat and human pancreas was thought to play a role in the development of pancreatic fibrosis (Bachem et al., 1998). They were stimulated to synthesize collagen due to oxidative stress (Casini et al., 2000). In such case the oxides generated during the metabolic processing of aflatoxin B1 results in oxidative stress that in turn induce stellate cells to produce collagen. Additionally, Perivascular mononuclear inflammatory cells and interlobular edema and mononuclear inflammatory cells infiltration were demonstrated in the pancreas of rat administered aflatoxin in accordance with previous studies (Beger et al., 2000; Şimşek et al., 2007 andAbd El-Haleem and Mohamed, 2011).Aflatoxin ingestion leads to reactive oxygen species production that regulates chemokine receptor expression and also facilitates the recruitment and localization of polymorphonuclear leukocyte to the site of infection and inflammation (Shephard, 2003).

In this study, there was paucity and cytoplasmic vacuolation in the langerhan's cells in compliance to previous researchers' obervations who recorded vacuolation of few islet cells and showed that most of the $\beta$ cells had rounded euchromatic nuclei, whereas some cells had small condensed heterochromatic nuclei (Abd El-Haleem and Mohamed, 2011).Aflatoxin as described previously induces oxidative stress due to generation of oxides and $\beta$ cells are particularly vulnerable to oxidative stress because of their low levels of antioxidant enzyme expression (Kaneto et al., 2005). Ensuing the damage to B cells, the serum glucose concentration is increased due to a decrease in serum insulin as evidenced in this study by increased random blood sugar in the group administered aflatoxins. On the other hand, the pancreatic lesions were remarkably alleviated in the groups administered aflatoxin and treated with coumarin and /or chlorophyll 
suggesting a protective effect of these treatments against oxidative stress induced by aflatoxin(Figure" $1 \mathrm{f}, \mathrm{g}, \mathrm{h}$ ).

The most predominant lesions observed in the kidneys of rats administered aflatoxin in the present study were congestion of intertubular blood vessels, hemorrhage, vacuolar degeneration and necrosis of tubular epithelium, presence of hyaline droplets in the lumen of renal tubules and focal areas of peritubular mononuclear inflammatory cells infiltration (Figur 1+1). Likewise to previous studies which recorded the dilatation and engorgement of renal blood vessels and intertubular capillaries with blood, focal areas of cloudy swellingof the lining epithelium of convoluted tubules together with presence of some eosinophilic debris in some lumen of other tubules and leucocytic cellular infiltration of renal interstitial tissues particularly lymphocytes with shrinkage of the glomerular tufts (El-ShewyandEbrahem , 2004). The groups that were administered coumarin and/ chlorophyll showed a remarkable improvement of the kidney lesions caused by aflatoxin(Figure "1j, k, l).
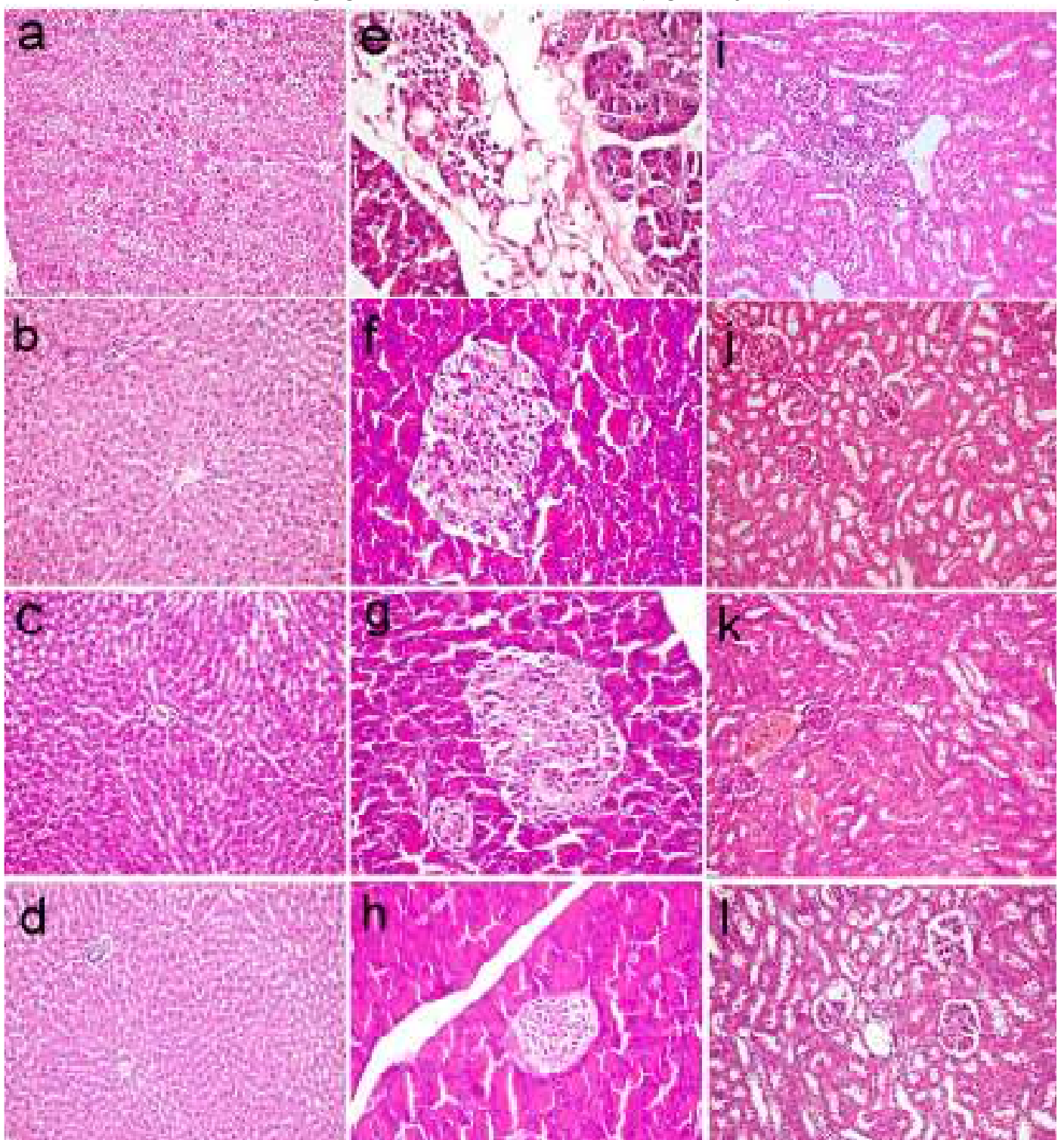

Figure 1. (a-d) Liver, rat. (a) vacuolation and karyomegaly of hepatocytes in G5 receiving aflatoxin 1000 ppb in diet. (b,c,d) apparently normal hepatocytes in G6 receiving aflatoxin in diet and coumarin in water, in G7 receiving aflatoxin in diet and chlorophyll in water and in G8 receiving aflatoxin in diet, coumarin and chlorophyll in water, respectively. (X 200). (e-h) Pancreas, rat. (e)Interlobular edema and mononuclear cells infiltration in $\mathbf{G 5}$ receiving aflatoxin in diet. (f, $g, h)$ showing apparently normal pancreatic structure (normal islets of langerhans and normal acini tissues G6 receiving aflatoxin in diet and coumarin in water, in $\mathbf{G} 7$ receiving aflatoxin in diet and chlorophyll in water and in G8 receiving aflatoxin in diet, coumarin and chlorophyll in water respectively (X 400).(i-l) Kidney, rat. (i) Focal area of peritubular mononuclear inflammatory cells infiltration in G5 receiving aflatoxin in diet. (j) Apparently normal renal structure with few intratubular casts in G6 receiving aflatoxin in diet and coumarin in water (k) congestion of intertubular blood vessels and slight vacuolation of renal tubular epithelium in $G 7$ receiving aflatoxin in diet and chlorophyll in water. (I)Apparently normal renal structure with vacuolation of few renal tubular epithelium in G8 receiving aflatoxin in diet, coumarin and chlorophyll in water (X 200).Hematoxylin and eosin stain. 
The beneficial effect of coumarin may be due to: 1Reduction ofaflatoxin $\mathrm{B}_{1}$-DNA adducts formation by both liver and intestinal microsomes (coumarin enhanced aflatoxicol formation therefore decrease aflatoxin $\mathrm{B}_{1}$-DNA adducts, because direct interaction of aflatoxicol-epoxide with DNA is minor compared with aflatoxin $\mathrm{B}_{1}$-epoxide(Loveland et al., 1987), 2Enhancement of glutathione $\mathrm{S}$ transferase (GST) activity in the intestine to conjugate aflatoxin $\mathrm{B}_{1}, 3$ Suppression of p 450 enzyme activity in the liver and enhancement of GST in the intestine (Tulayakul et al., 2007); 4- improving liver function (Gilani and Janbaz, 1993) and body health (Maucher et al., 1994; Hoult and Paya, 1996; Pillai et al., 1999; Devienne et al., 2005) and 5- increasing the digestibility of crude protein and ether extract (Ko et al., 2006).

\section{CONCLUSION}

Results indicated that addition of coumrin and / or chlorophyll to rat aflatoxin contaminated diet was safe and practical meth.

\section{REFERENCES}

A.O.A.C.(2006). Association of official analytical chemists of official methods of analysis, $18^{\text {th }} \mathrm{ed}$, Washington. D . C.

Abd El-Baki, S. M; Nower, M. S; Hassona, E. A; Bassuny, S. M and Shehata, S. A.(2002). Clays in animal nutrition: 10-Detoxification of aflatoxin $B_{1}$ by tafla clay in rabbit feeds. $3^{\text {rd }}$ Sci. Con. On Rabbit Production in Hot Climates, 8-11 Oct., Hurgada, Egypt, pp. 557-567.

Abd El-Haleem, Manal Reda and Mohamed, Dalia, A. (2011). The effects of experimental aflatoxicosis on the pancreas of adult male albino rats and the role of ginger supplementation: a histological and biochemical study The Egyptian Journal of Histology: 34 - (3): p 423-435.

Abdelhamid, A. M.(2005a). Carcinogens $1^{\text {st }}$ Ed., Dar Anashr for universities, Cairo, Egypt, Deposit No. 1949/2005, ISBN : 977-316-149-8.

Abdelhamid, A.M.(2005b). Mycotoxicoses in fish with special emphasis on the Egyptian situation . Proc. $12^{\text {th }}$ Inter . Con., 19-24 Nov., Al-Hodeidah Univ., Yemen, J. Union Arab Biol. Cairo, 24A (Zoology):185-214. ( engomix.com, mycotoxins Technical Articles, 2007,13p).

Abdelhamid,A.M.(2009). Thirty years (1978-2008) of mycotoxin research at faculty of agricultur, Mansoura University, Egypt. Egyptian J. Nutrition and feeds. 12(1): 1-19.

Abdelhamid,A.M; Ahmed,A.M and El-Meleigy,K.M. (2002). Detoxification of aflatoxinscontaminated diet by some physical and chemical means. J. Agric. Sci. Mansoura Univ., 27: 82138229.

Abdel-Wahhab , M.A. ; Nada , S.A. and Khalil F.A. (2002).Physiological and toxicological responses in rats fed aflatoxin contaminated diet with or without sorbent materials. Animal Feed Science and Toxicology, 97(314):209-219.
Agag,B.I.(2003). Prevention and control of mycotoxins in feeds AssiutUniv-Bull-Environ.Res., 6: 149-166.

Helal, Amera A.A.; Shehata, S.A. Naser A.E and Ayyat, M.S.(2014). Effect of coumarin supplementation to growing rabbit diets on alleviation the toxicity of aflatoxinB1 ,Zagazig J. Agric. Res., 41: (4) .

Bachem, M.G; Schneider, E; Gross, H; Weidenbach, H;Schmid, R.M;Menke, A; Siech, M; Beger, H;Grünert, A and Adler, G.(1998). Identification, culture and characterization of pancreatic stellate cells in rats and humans Gastroenterology. 115:421-432

Beger, H.G; Gansauge, F and Mayer, J.M.(2000).The role of immunocytes in acute and chronic pancreatitis: when friends turn into enemies Gastroenterology, 118:626-629

Bhattacharyya, S. S ; Mandal, S. K ; Biswas, R; Panl, S; Pathak, S; Boujedaini,N; Belan,P and KhudaBukhsh,A.R.(2008).In vitro Studies demonstrate anticancer activity of an alkaloid of the Gelsemiumsempervirens. EXP. Biol. Med. (Maywood), 233(12) :1591-1601.

Bhattacharyya,S.S; Paul,S; Mandal,S.K; Banerjee,A and Khuda-Bukhsh, A. R. (2009). A coumarin (4methyl-7-hydroxy coumarin) has anti-cancer potentials against DMBA-induce cancer in mice. Eur.J. Pharmacology, 614(1-3): 128-136.

Casini, A;Galli, A;Pignalosa, P;Frulloni, L;Grappone, C; Milani, S; Pederzoli, P; Cavallini, G and Surrenti, C.(2000). Collagen type I synthesized by pancreatic periacinar stellate cells (PSC) colocalizes with lipid peroxidation-derived aldehydes in chronic alcoholic pancreatitis $\mathrm{J}$ Pathol. 192:81-89.

Casly-Smith, J.R; Morgan,R.G and Piller,N.I.(1993). Treatment of Iymphedema of the arms and with 5, 6-benzo (alpha)-pyrone. New England J. of Medicine, 329: 1158-1163.

Dashwood, R; Negishi,T; Hayatsu,H; Breinholt, V; Hendricks, J and Bailey,G.(1998). Chemopreventive properties of chlorophylls towards aflatoxin $\mathrm{B}_{1}$ :a review of the antimutagenicity and anti-carcinogenicity data in rainbow trout. Mutation Res., 399(2): 245-253.

Davis, N.D; Diener, U.L and Eldridge, D.W.( 1966). Production of aflatoxins B1 and G1 by Aspergillusflavus in a semisynthetic medium. Applied Microbiology 14: 378-380.

Deng,S.X; Tian,L.X; Liu,F.J; Jin,S.J; Ling,G.Y; Yang,H.J; Zhen,D.R and Liu,Y.J.(2010). Toxic effect and residue of aflatoxin $\mathrm{B}$ 1in tilapia (Oreochromisniloticus x O. aureus) during long term dietary exposure. Aquaculture, 307(3-4): 233-240.

Devienne, K.F ; Reddi, M. S. G; Coelho, R.G. and Viledgas, w. (2005).structure-anti microbial activity some natural isocoumarins and their analogues. Phytomedicine, 12(5): 78-381.

EL-Shewy, Elham. A. and Mona F. Ebrahem. (2004).Amelioration effect of vitamin against the toxicity of aflatoxin $B_{1}$ on rats with apecial reference to its effect to its effect on male fertility 1rst Ann. Confr., FVM., Moshtohor. 
Enger, P. A; Munoz, A and Kensler, T.W.(2003). Chemoprevention with chlorophyllin in individuals exposed to dietary aflatoxin. Mutation Res., 523-524 .

Furniss, B.S; Hannaford ,A.J; Smith, P.W.G and Tatchel, A.R.(1989). Vogel 's Textbook of Practical Organic Chemistry. UK: Wiley, Pearson Education Ltd

Goeger, D. E; Anderson, K. E. and Hsie, A. W. (1998).Coumarinchemoprotection against aflatoxin B1-induced gene mutation in a mammalian cell system: A species difference in mutagen activation and protection with chick embryo and rat liver S9 Enviromental and Molecular Mutagenesis, 32:64-74 .

Gilani, A. H. and Janbaz, K. H. (1993).Protective effect of Artemisia scoparia extract against acetaminophen induced hepatotoxicity. Gen. Pharmac. 24, 1455-1458.

Hoult,J.R.s and Paya,M.(1996). Pharmacological and biochemical action of simple coumarins: Natural products with therapeutic potential. General pharmacology: The Vascular System, 27 (4): 713-722.

Kaneto, H;Kawamori, D; Matsuoka, T.A;Kajimoto, Y andYamasaki ,Y.(2005).Oxidative stress and pancreatic beta-cell dysfunction Am J Ther. 12:529-533

Kelly,V.P; Ellis,E.M; Manson,M.M; Chanas,S.A; Moffat,G.J; Judah,D.J; Neal,G.E and Hayes,J.D. (2000). Chemoprevention of aflatoxin $\mathrm{B}_{1}$ hepatocarcinogenesis by coumarin, a natural beenzopyrone that is a potent inducer of aflatoxin $\mathrm{B}_{1}$-aldehyde reductase, the glutathione $\mathrm{S}$ transferase A5 and $\mathrm{P} 1$ subunits, and NAD (P)H: quinine oxidoreductase in rat liver. Cancer Research, 60:957-969.

Kensler,T.W ; Enger, P.A; Wang,J.B ; Zhu,Y.R; Zhang,B.C ; Qian,G.S ; Kuang,S.Y; Gange,S.J; Jacobson,L.P; Munoz,A and groopman,J.D. (2002). Strategies for chemoprevention of liver cancer. European J Cancer Prevention, 11(2): 5864.

Ko, Y.D., J.H. Kim, A.T. Adesogan, H.M. Ha and S.C. Kim (2006).The effect of replacing rice straw with dry wormwood (Artemisia sp.) on intake, digestibility, nitrogen balance and ruminal fermentation characteristics in sheep. Animal Feed Sci. and Technol., 125: 99-110.

Kumar,M; Verma,V; Naqpal,R; Kumar,A; Behara,P.; Singh,B and Aggarwal,.K.(2012).Anticacinogenic effect of probiotic fermented milk and chlorophullin on aflatoxin $\mathrm{B}_{1}$ induced liver carcinogensis in rats. Britrish J. Nutrition, 107(7): 1006-1016.

Lake,B.G; Gray,T.J.B; Evans, J.G; Lewis,D.F.V; Beamand, J.A. and Hue ,K.L.(1989).Studies on the mechanism of coumarin induced toxicity in rat hepatocytes: comparison with dihydrocoumarin and other coumarin metabolites. Toxicology and Applied Pharmacology, 97: 311-323.
Loveland, P.M., J.S. Wilcox, N.E. Pawlowski and G.S. Bailey (1987). Metabolism and DNA binding of aflatoxicol and aflatoxin $\mathrm{B}_{1}$ in vivo and in isolated hepatocytes from rainbow trout (Salmogairdneri). Carcinogenesis, 8: 1065-1070.

Maria, I.F.M and Asker,A.A.(2008).Aflatoxins in rabbit production: Hazards and control. Tropical and Subtropical Agroecosystem, 8: 1-28.

Matri,A.(2001). Identification of fungal contamination and determination of mycotoxigenic molds by micellar electro kinetic capillary chromatography in smoked paprika. Journal of Food Protection , 68: 815-822.

Maucher, A; Kager, M. and Von Angerer, E. (1994). Anti-tumor activity of coumarin in prostate and mammary cancer models. J. Cancer Res. and Clinical Oncology, 120 (8):514-516.

Mehrim,A; Refaey,M.M and ElMeleigy,K.M.(2016).Glutathion-EnhacerAgainst Foodborne Aflatoxicosis of Oreochromisniloticus. J. Fish. Aquat. Sci., 11(2): 131-146.

Meshreky, S.Z., Mervat, M., Arafa, M. A., Abo, W. and Gad Alla S.A.Z. (2007).Male and female rabbits performance traits as affected by dietary aflatoxin contamination and its detoxification. Egyptian Journal of Rabbit Science, 17 (1): 2742.

Naidu,N.R.G.; Sehgal,S.; Bhaskar,K.V.S. and Aikat, B.K. (1991).Cystic disease of the liver following prenatal and perinatal exposure to aflatoxin B1 in rats. Journal of Gastroenterology and Hepatology,6(4):359-362.

Pillai,S.P; Menon,S.R; Mitscher,L.A; Pillai,C.A and Shankel,D.M.(1999). Umbelliferone analogues and their potential to inhibit benzo (a) pyrene and hydrogen peroxide-induced mutation. J, Natural products, 62(10): 1356-1362.

Prince,M; Li,Y; Childers,A; Itoh,K; Yamamoto,M and Kleiner,H.E.(2009). Comparison of citrus coumarins on carcinogen-detoxifying enzymes in Nrf2 knockout mice. Toxicological Letters, 3: 180-186.

Roos,A.H; Van der Kamp,H.J and Marley,E.C.(1997). Comparison of immunoaffinity columns with Florisil/C18 columns for the determination of aflatoxins in animal feed and maize mycotoxin Res, 13:2-10.

Salem,M.H.; Kamel,K.I.; Yousef,M.I.;Hassan,G.A. and El-Nouty, F.D. (2001).Protective role of ascorbic acid to enhance semen quality of rabbits treated with sublethal doses of aflatoxin B1. Toxicology, 162(3):209-218.

Shehata,S.A.(2002). Detoxification of mycotoxin contaminated animal feed stuffs. Ph.D Thesis, ZagazigUniv.,Fac. Of Arabic., Egypt.

Shehata,S.A; El-Melegy,M and Ebrahim,M.S.(2009a). Toxicity reduction aflatoxin $\mathrm{B}_{1}$ by vitamin $\mathrm{C}$ in fish .J. of the Arabian Aquaculture Society,4(2): 73-86. 
Shehata,S.A; El-Melegy,M and Ebrahim,M.S and Abou-Seif,R.A.(2009b).Aflatoxin $\quad B_{1}$ toxicity reduction by tafla, honey Society, 4(1): 55-72.

Shehata,S.A.(2010). Effect of adding Nigella sativa and vitamin $\mathrm{C}$ to rabbit diet contaminated aflatoxin $\mathrm{B}_{1}$. Egyption J. Nutrition and feeds, 13(1): 137 148.

Shephard, G.S.(2003).Aflatoxin and food safety: recent African perspectives J.Toxicol.Toxin. Rev., 22:267-286.

Shio, Y., (2006), Large Scale Chlorophyll Using Simple Open-Column Chromatographi Methods, Springer, Netherlands, pp. 123-131.

Shouman,B.O; El Morsi,D; Shabaan,S; AbdelHamid,A.H and Mehrim,A. (2012). Aflatoxin B level in reelation to child's feeding and growth. Indian J Pediatr, 79(1):56-61.

Simonich,M.T; Enger,P.A; Roebuck,B.D; Orner,G.A; Jubert, C; Pereira,C; Groopman,J.D; Kensler,T.W; Dashwood,R.H; Williams,D.E and Bailey,G.S.(2007). Natural chlorophyll inhibits aflatoxin $\mathrm{B}_{1}$ - induced multi-organ carcinogensis in the rat. Carcinogensis, 28 (6): 1294-1302.

Simonich,M.T; Mcquistan,T; Jubert,C; Pereira,C; Hendricks,J.D; $\quad$ Schimerlik,M; Zhu,B; Dashwood,R.H; Williams,D.E and Bailey,G.S .(2008). Low-dose dietary chlorophyll inhibits multi-organ carcinogensis in the rainbow trout Food Chemical Toxicology, 46(3): 1014-1024.

Şimşek, N; Ergun, L; Ergun, E;Alabay, B and Essiz, D.(2007).The effects of experimental aflatoxicosis on the exocrine pancreas in quails (Coturnixcoturnix japonica) Arch Toxicol. $81: 583-588$
Srivastava,A.K. (1984). Pharmaco Kinetics and therapeutic evaluation of oximes buffalo caves. Ph.D. Thesis, Punjab Agric. Univ., Ludhiana, India.

Sudakin,D.L.(2003). Dietary aflatoxin exposure and chemoprevention of cancer: a clinical review.J. Toxicology Clinical Toxicology, 41 (2). 195-204.

Suendo, V.; Division, P. C.; Sciences, N. and Barat, J. (2010). isolation of chlorophyll a from spinch and its modification using $\mathrm{Fe}^{2+}$ in photostability 1 Introduction, (Icmns), 859-873.

Suvarna, S.K., Layton, C. and Bancroft, J.D.(2012). Bancroft's Theory and Practice of Histological Techniques. 7th ed. New York: Churchill Livingstone.

Tulayakul, P; Dong, K.S; Li, J.Y;Manabe, N and Kumagai, S. (2007). The effect of feeding piglets with the diet containing green tea extracts or coumarin on in vitro metabolism of aflatoxin B1 by their tissues. Toxicon, 50 (3): 339-348.

Vyas,K.B; Nimavat,K.S; Jani,G.R and Hathi, M.V.(2009). Synthesis and antimicrobial activity of coumarin derivatives metal complex: An in vitro evaluation .Orbital, 1(2): 183-192.

Zaky,Z.M; Sharkawy,A.A; Mubarak,M and Ahmed,A.I. (2000).Effect of some immunostimulants on aflatoxicosis in ducks. Proc. Conf. Mycotoxinsand Dioxins and the Environment, Bydgoszcz, 25-27. Sep., pp. 93-1

Zohair, Azza.(1996). Destruction of aflatoxin in peanut and Peanut products, $\mathrm{PhD}$, Ain Shams University. Cairo, Egypt.

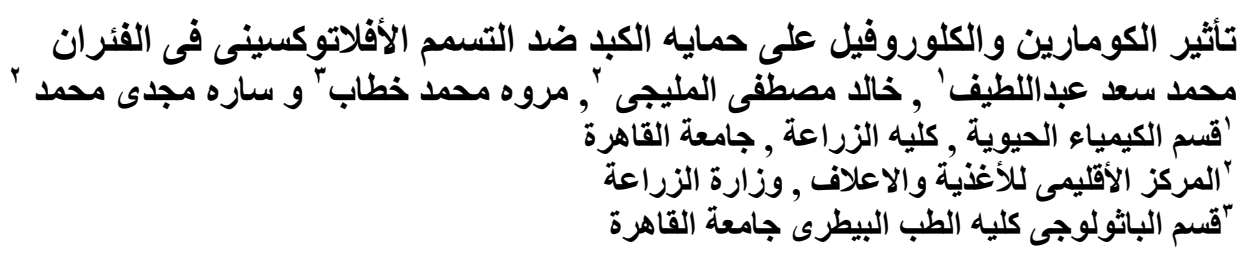

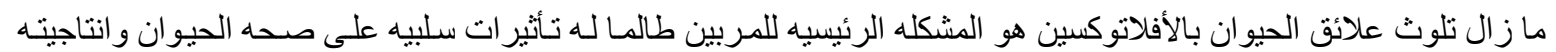

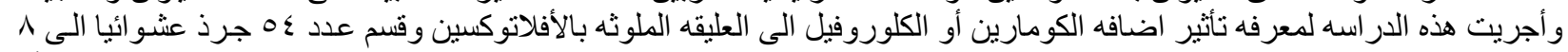

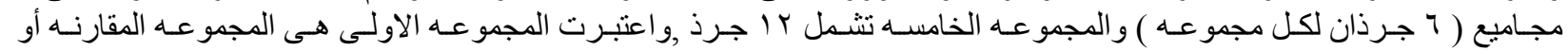

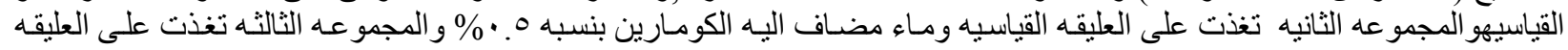

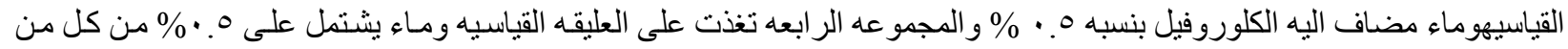

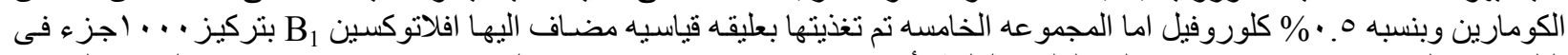

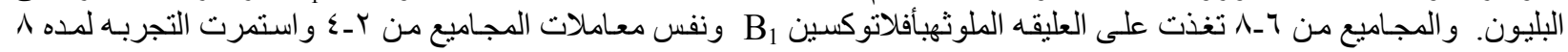

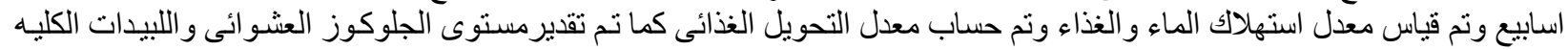

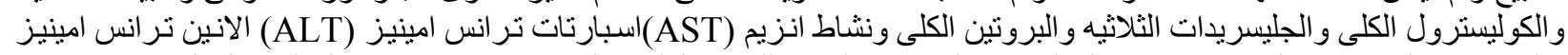

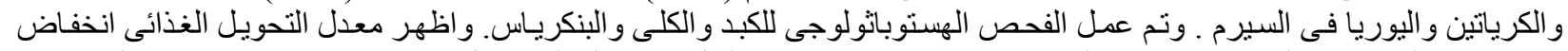

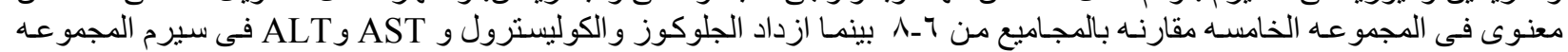

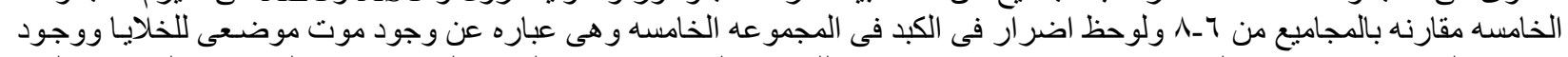

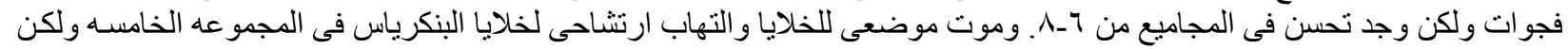

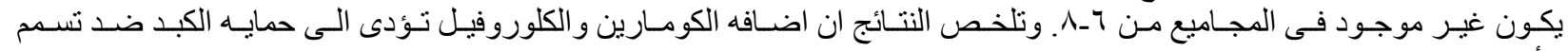

